\title{
Acid Distribution and Durability of HT-PEM Fuel Cells with Different Electrode Supports
}

Kannan, A.; Li, Q.; Cleemann, L. N.; Jensen, J. O.

Published in:

Fuel Cells

Link to article, DOI:

10.1002/fuce.201700181

Publication date:

2018

Document Version

Peer reviewed version

Link back to DTU Orbit

Citation (APA):

Kannan, A., Li, Q., Cleemann, L. N., \& Jensen, J. O. (2018). Acid Distribution and Durability of HT-PEM Fuel Cells with Different Electrode Supports. Fuel Cells, 18(2), 103-112. https://doi.org/10.1002/fuce.201700181

\section{General rights}

Copyright and moral rights for the publications made accessible in the public portal are retained by the authors and/or other copyright owners and it is a condition of accessing publications that users recognise and abide by the legal requirements associated with these rights.

- Users may download and print one copy of any publication from the public portal for the purpose of private study or research.

- You may not further distribute the material or use it for any profit-making activity or commercial gain

- You may freely distribute the URL identifying the publication in the public portal

If you believe that this document breaches copyright please contact us providing details, and we will remove access to the work immediately and investigate your claim. 


\section{Acid Distribution and Durability of HT-PEM Fuel Cells with Different Electrode Supports}

\begin{tabular}{|r|l|}
\hline Journal: & Fuel Cells \\
\hline Manuscript ID & Draft \\
\hline Wiley - Manuscript type: & Original Research Paper \\
\hline Date Submitted by the Author: & n/a \\
\hline Complete List of Authors: & $\begin{array}{l}\text { Kannan, Arvind; Technical University of Denmark, DTU Energy } \\
\text { Li, Qingfeng; Technical University of Denmark, Department of Energy } \\
\text { Conversion and Storage } \\
\text { Cleemann, Lars; Technical University of Denmark, DTU Energy } \\
\text { Jensen, Jens Oluf; Technical University of Denmark, DTU Energy }\end{array}$ \\
\hline Keywords: & $\begin{array}{l}\text { PEMFC, HT-PEMFC, Polybenzimidazole (PBI), Phosphoric acid, Gas diffusion } \\
\text { layer, Durability, Fuel cells, Electrochemistry }\end{array}$ \\
\hline &
\end{tabular}




\title{
Acid Distribution and Durability of HT-PEM Fuel Cells with
}

\section{Different Electrode Supports}

\author{
Arvind Kannan ${ }^{1}$, Qingfeng $\mathrm{Li}^{1}$, Lars N Cleemann ${ }^{1}$, Jens Oluf Jensen ${ }^{1, *}$ \\ Department of Energy Conversion and Storage, Kemitorvet 207, Technical University of \\ Denmark, 2800 Kgs. Lyngby, Denmark
}

[*]Corresponding author: jojen@ dtu.dk

\begin{abstract}
The durability of high-temperature polymer electrolyte membrane fuel cells (HT-PEMFC) was studied with phosphoric acid doped membranes of polybenzimidazole (PBI). One of the challenges for this technology is the loss and instability of phosphoric acid resulting in performance degradation after long-term operation. The effect of the gas diffusion layers (GDL) on acid loss was studied. Four different commercially available GDLs were subjected to passive ex-situ acid uptake by capillary forces and the acid distribution mapped over the cross-section. Materials with an apparent fine structure made from carbon black took up much more acid than materials with a more coarse apparent structure made from graphitized carbon. The same trend was evident from thermally accelerated fuel cell tests at $180{ }^{\circ} \mathrm{C}$ under constant load, where degradation rates depended strongly on the choice of GDL material, especially on the cathode side. Acid was collected from the fuel cell exhaust at rates clearly correlated to the fuel cell degradation rates, but amounted to only a few percents of the total acid content in the cell even after significant degradation. Long-term durability of more than $5500 \mathrm{~h}$ with a degradation rate of $12 \mu \mathrm{Vh}^{-1}$ at $180{ }^{\circ} \mathrm{C}$ and $200 \mathrm{~mA} \mathrm{~cm}$ - was demonstrated with the most acid retaining GDL material.
\end{abstract}




\begin{abstract}
Keywords: PEM fuel cell, Polybenzimidazole, Phosphoric acid, Gas diffusion layers, Durability, Fuel cells, Electrochemistry
\end{abstract}

\title{
1. Introduction
}

Fuel cells are electrochemical energy conversion devices that can efficiently convert chemical energy directly into electrical energy. Proton electrolyte membrane fuel cells (PEMFCs) have attracted much attention due to their promise for both mobile and stationary applications. Wainright et al. [1] doped $m$-polybenzimidazole films with phosphoric acid (PA) and demonstrated fuel cell operation of these membranes at temperatures of $100-200{ }^{\circ} \mathrm{C}$. A polymer electrolyte membrane operating above $100{ }^{\circ} \mathrm{C}$ without humidification offers many benefits which include potentially fast electrode kinetics, high tolerance to fuel impurities and simplified water/thermal management, and higher system efficiencies.[2] Fuel cell durability targets a range from $10,000 \mathrm{~h}$ for automotive applications to $80,000 \mathrm{~h}$ for stationary applications.[3] For further development of high temperature (HT-) PEMFCs, significant attention has been focused upon fundamentally understanding degradation and in development of strategies to improve the fuel cell durability. Long-term durability of HTPEMFCs has been well demonstrated under steady state operation at intermediate temperatures of $150-160^{\circ} \mathrm{C}$. Schmidt [4] and Oono et al. [5,6] reported tests over $18,000 \mathrm{~h}$, with an average degradation rate of 4-6 $\mu \mathrm{V} \mathrm{h}^{-1}$. Søndergård et al. [7] recently reported a test for over 13,000 hours with a thermally cross-linked membranes. During the first 9200 hours a degradation rate as low as $0.5 \mu \mathrm{Vh}^{-1}$ was observed. During the extended operation from 9200 to 13000 hours, however, the degradation rate was found to be around $5 \mu \mathrm{V} \mathrm{h}{ }^{-1}$. The acceleration of degradation after long-term operation has been attributed to the cumulative acid loss and the resultant membrane thinning and catalyst deterioration. [5,8]

Careful design considerations need to be adopted for components of the membrane electrode assembly (MEA). Significant efforts have been made to develop membranes [9-12], catalysts 
[13-15] and electrodes [16-18] as well as bipolar plates [19]. The present paper is devoted to a study on the impact of gas diffusion layer (GDL) materials on mitigation of acid loss and fuel cell durability. The purpose of the electrode support or GDL is to supply gaseous reactants and remove the byproduct water from the cathode side. GDLs have to be, at the same time, electrically and thermally conducting for electron conduction and heat removal from the active area and are therefore porous materials made of carbon fibers in either woven or non-woven forms. During assembling fuel cells, the GDL should provide mechanical support to the MEA and prevent it from sinking into the flow field channels. In the uncompressed state, the GDL porosities are in the range of $70-90 \%$ with mean pore diameters of about $30-80 \mu \mathrm{m}$ [20]. Electric contact resistance is minimized by applying compressive stress, resulting in compression rates of $10-40 \%$ [21]. This carbon fiber layer is often wet-proofed by treatment with polytetrafluoroethylene (PTFE). On top of the carbon fiber layer a microporous layer (MPL) is prepared from carbon powders with polymeric binders in order to smooth the surface onto which catalyst powders are applied during the electrode fabrication. This MPL layer is essential to minimize the contact resistance between the GDL and catalyst layer. The most often used binder is PTFE, which makes the MPL hydrophobic. In low temperature (LT-) PEMFCs, a major role of the MPL is to improve the water management and enhance the fuel cell performance at high current densities by preventing the electrodes from flooding[22]. In HT-PEMFCs water is formed as vapor and the electrode flooding is not an issue any more. On the other hand, the GDL and MPL (in the following discussion, the term GDL is also used to refer the material consisting of the carbon fiber layer and MPL) have an addition function i.e. to facilitate the acid retention in the fuel cell. In this connection, early year efforts were made to determine the acid uptake by the gas diffusion electrodes and its impact performance of phosphoric acid fuel cells [26,36].

Phosphoric acid is doped into the polymer membranes by acid-base interaction as well as physical adsorption. When equilibrated in an aqueous solution of the acid, e.g. $85 \mathrm{wt} \%$ 
$\mathrm{H}_{3} \mathrm{PO}_{4}$, an acid doping level is achieved of about 9.5 mol $\mathrm{H}_{3} \mathrm{PO}_{4}$ per repeat unit of the polymer. When brought into a close contact with the catalyst layer of electrodes the acid is driven into the catalyst layer by the capillary force, depending on the micropore structures of the carbon, hydrophobicity characteristics of the layer and the surface tension of the acid. This acid redistribution phenomenon is often referred to as the break-in process at the start-up of HT-PEMFCs when the cell performance slowly improves to reach a steady state within a few hundred hours[18,23]. Only a few publications focus on investigation of the GDL for HTPEMFCs. The early year study was performed using carbon paper purchased from Toray (TGP-H-120) wet-proofed and coated with an MPL $[16,24,25]$. The utilization of PTFE seems to play a critical role in performance as it can control the migration of phosphoric acid from the membrane electrolyte to the catalyst layer [26] and farther in the microporous layer [27]. Lobato et al.[25,27] investigated the cell performance with and without including a MPL on both cathode and anode. It was found out that the presence of a MPL improves the adhesion between catalyst layer and GDL and is beneficial to the performance of HT-PEMFCs. Recent work of Chevalier et al. [28] was based on the Freudenberg H23C2 product, a GDL with an MPL made of non-woven carbon cloth. It was clearly shown that at the catalyst layer/MPL interface there were cracks, through which the PA invasion into the GDL occurs. The authors concluded that the microstructure of the porous layers and the catalyst layer is an influencing factor on the locations of acid filling of GDL pores and consequently on the leaching of acid. Maier et al. showed the redistribution of PA with a structural change within C2 based electrodes along flow channels in the through plane configuration, as non-uniform PA distribution was observed by local transmittance variations with the synchrotron X-ray radiography [29]. Eberhardt et al. observed in operando visualizations of phosphoric acid followed a tortuous path through cracks in the MPL and numerous pores within the fibrous substrate to eventually reach the channel of the flow fields $[30,31]$. 
In addition to the above mentioned materials and components, operational factors also impact on the loss of acid in the fuel cell environment such as temperature [32,33], load [34,35] and reactant flow rates $[19,34]$. The current density and flow rate can both influence the PA concentration and its penetration within the GDE[29]. Oono et al. [5,6] used the electron probe micro-analysis and transmission electron microscopy to investigate the phosphoric acid redistribution and loss in MEAs operated at $150^{\circ} \mathrm{C}_{\text {and }} 200 \mathrm{mAcm}^{-2}$ before and after the long term tests. Their results indicated a decline in the PA content in the membrane and the electrodes with time. They indicated that acid depletion from the membrane into the electrodes could be the reason for degradation of cells during long term tests. It should be mentioned that Oono et al. [32] studied the effects of cell temperatures by long term durability tests at $150^{\circ} \mathrm{C} .170^{\circ} \mathrm{C} .190^{\circ} \mathrm{C}$ and observed a $10 \%$ cell voltage drop after 17000 , 6400 and $1000 \mathrm{~h}$, respectively. Yu et al.[12] operated cells at typical operating temperature of $160^{\circ} \mathrm{C}$ and $190^{\circ} \mathrm{C}$ with a voltage degradation rate of $4.9 \mu \mathrm{V} \mathrm{h}^{-1}$ and $60 \mu \mathrm{V} \mathrm{h}^{-1}$ and an acid loss rate of $7.6 \mathrm{ng} \mathrm{cm}^{-2} \mathrm{~h}^{-1}$ and $110.4 \mathrm{ng} \mathrm{cm}^{-2} \mathrm{~h}^{-1}$, respectively. Søndergård et al. [39] reported an even stronger temperature effect at higher stoichiometries of hydrogen and air. In this work, the fuel cell operational temperature of $180{ }^{\circ} \mathrm{C}$ was selected as a stressor to the long term durability test of HT-PEMFCs with varied gas diffusion layer materials.

\section{Experimental}

\subsection{Gas Diffusion Layers}

Four types of commercially available GDLs from Freudenberg (FCCT, Germany) are investigated i.e. $\mathrm{H} 23 \mathrm{C} 2, \mathrm{H} 23 \mathrm{C} 3, \mathrm{H} 23 \mathrm{C} 4$ and $\mathrm{H} 24 \mathrm{C} 5$, referred to as $\mathrm{C} 2, \mathrm{C} 3, \mathrm{C} 4$ and $\mathrm{C} 5$, respectively. Table 1 shows properties of these materials used in this study. The differences in the MPL are the carbon structure and PTFE content while in the GDL backing layer is either PTFE treated or non-treated. In the MPL, C2 is as the reference material with $40 \%$ PTFE and $60 \%$ carbon black, having area specific resistance of $10 \mathrm{~m} \Omega . \mathrm{cm}^{-2}$ and tensile strength of 1.6 
$\mathrm{Nmm}^{-1}$. C4 has twice reduced PTFE content compared with $\mathrm{C} 2$ with area specific resistance of $8 \mathrm{~m} \Omega . \mathrm{cm}^{-2}$ and tensile strength of $1.6 \mathrm{Nmm}^{-1}$. C3 and C5 with the similar PTFE content as C4 but using graphitized carbon instead of carbon black, possessing area specific resistance of $9 \mathrm{~m} \Omega . \mathrm{cm}^{-2}$ and tensile strength of $1.4 \mathrm{Nmm}^{-1}$. Moreover $\mathrm{C} 3$ has an additional hydrophobic treatment of the backing layer, which likely affects the penetration of MPL into the fiber layer. There is a slight increase in the thickness and area weight.

\subsection{Acid distribution on GDL samples}

The acid uptake of the gas diffusion layers was first measured. The microporous layer of the GDL $\left(10 \mathrm{~cm}^{2}\right)$ was made in contact with a carbon felt of thickness $4 \mathrm{~mm}$ containing $0.5 \mathrm{gcm}^{-2}$ of phosphoric acid. The vessel was maintained at $160{ }^{\circ} \mathrm{C}$. On a daily basis acid absorbed on the samples were determined gravimetrically for a period of about 200 hours, followed by EDS examination of the phosphorous distribution.

\subsection{Application of Catalyst layer}

For fabrication of gas diffusion electrodes (GDE) a catalytic ink was prepared by mixing the catalyst (Pt 60 wt\% on carbon black, Johnson Matthey, Hispec 9100) and ethanol (96\% v/v) as solvent in the ratio 1:50 (w/w). The ink was then subjected to ultra-sonication for $1 \mathrm{~h}$ for good dispersion. Electrodes were prepared by spraying the catalytic ink over the microporous layer of the GDL with an active surface of $25 \mathrm{~cm}^{2}$ with Pt loading of about $0.25 \mathrm{mgcm}^{2}$ for anode and $0.72 \mathrm{mgcm}^{2}$ for cathode. Catalyst deposition technique using the ultrasonic spraying robot (Sonotec Exactacoat) working at a flow rate of $0.25 \mathrm{ml} \mathrm{min}^{-1}$ and a needlesubstrate distance of $13 \mathrm{~cm}$ has demonstrated high reproducibility in producing thin film coatings [18].

\subsection{MEA Fabrication}

PBI membranes (Dapozol) used for this study were supplied by Danish Power Systems obtained in an acid-free form with a thickness of $c$ a $40 \mu \mathrm{m}$. The membranes were immersed 
in an $85 \%$ phosphoric acid solution at room temperature until use, i.e. more than 500 hours. Doped membranes of about 9.5 molecules of PA per repeating unit of PBI was wiped off for superficial acid with lab tissues. The MEA was assembled directly in the fuel cell hardware with torque of $2 \mathrm{Nm}$ by sandwiching the doped membrane between two GDEs without prior hot-pressing. The flow plates consisted in machined graphite plates with 5 parallel channels in a serpentine flow pattern incorporated with gaskets made of fluorinated polymer (Viton). A nonreactive sub gasket frame made of polyimide was introduced in order to reinforce the fringe of membrane along the periphery of the electrodes. The active area of the resulting MEAs was $23 \mathrm{~cm}^{2}$.

\subsection{Fuel cell Characterization}

Fuel cells were mounted onto test stations of an in-house build test rack. The set point temperature for each cell was maintained using CAL 3300 PID temperature controllers. Brooks GF 80 thermal mass flow controllers were used to control the feeding gases at constant stoichiometric flows of 1.5 for hydrogen at the anode and 2 for air at the cathode side, respectively, without prior humidification or pressurization. Fuel cells were controlled and monitored using a LabVIEW interface during steady state operation. The cells were tested under steady state operation with a galvanostatic current load of $200 \mathrm{~mA} \mathrm{~cm}$-2 at elevated temperature of $180{ }^{\circ} \mathrm{C}$. The polarization curves were taken with an electronic load operating in galvanostatic mode and the voltage of the cell was recorded after $90 \mathrm{sec}$ of running at each set current density. The flow rate equivalent to $200 \mathrm{~mA} \mathrm{~cm}{ }^{-2}$ was used for lower current densities and for current densities above $200 \mathrm{~mA} \mathrm{~cm} \mathrm{~cm}^{-2}$ stoichiometric flows were maintained as 1.5 for hydrogen and 2 for air. Electrochemical impedance spectroscopy (EIS) was performed with a frequency response analyzer coupled to a potentiostat/galvanostat (Versastat 4) with $\mathrm{AC}$ amplitude of $200 \mathrm{~mA}$ in the frequency range of $0.01 \mathrm{~Hz} 100 \mathrm{kHz}$. In order to determine the phosphoric acid loss during fuel cell operation, the exhaust gas stream was bubbled through a water bath of $100 \mathrm{~g}$ at room temperature and the water with condensed acid 
was collected every month. The water sample containing phosphoric acid was analyzed to measure phosphorus content by inductively coupled plasma - optical emission spectroscopy.

\subsection{Acid distribution on MEA samples}

A scanning electron microscope (SEM, Zeiss EVO MA10) incorporated with an Oxford Energy-Dispersive X-ray Spectrometer (EDS) was used for examining the surface morphologies of GDLs and cross-section of the GDLs and MEA. A clean cut of the crosssection was achieved by ion milling (Hitachi E-3500). Elemental compositions can be observed by the distribution and density of pixel based on X-ray total counts in specific energy window recorded and displayed on the images. The energy of the incident beam was set to $15 \mathrm{keV}$ accelerating voltage. The focal distance determining the geometry between EDS detector and specimens was set in the range of $7.5 \mathrm{~mm}$ and $8 \mathrm{~mm}$ to obtain decent count rates for elemental analysis. The beam current as a probe size was set to $3 \mathrm{nA}$ to acquire enough signals and count rate. For phosphorous mapping, the sampling time was 300-360 minutes with data acquisition of each point set to 20 seconds.

\section{Results and discussion}

\subsection{Morphology and acid uptake}

Figure 1 shows SEM images of the surface morphologies of the MPL sides of C2 based on carbon black and of $\mathrm{C} 3$ based on graphitized carbon. It is evident that the MPL of C2 has a fine structure with perforations and cracks on the surface while the MPL of C3 has a much coarser structure with voids and ridges on the surface. The surfaces of C4 and C5 appeared very similar to those of $\mathrm{C} 2$ and $\mathrm{C} 3$, respectively (even number: fine surface, odd number: coarse surface) and are not shown. All four surfaces were examined both sides by EDS and the PTFE content was estimated based on the fluorine to carbon ratio measured. The numbers were added to table 1. The accuracy of EDS analyses of light elements is known to be limited, but the numbers obtained correspond well with the data provided for the MPLs by the 
supplier. Moreover, the extra wet proofing of $\mathrm{C} 3$ is clearly confirmed by a ca four-fold higher PTFE content of $\mathrm{C} 3$ as compared with the other materials, see Table 1.

The acid uptake of C2, C3, C4, and C5 by contact of the MPL side with acid filled carbon felt was measured over time and plotted in figure 2. Each of the data points corresponds to an average of 9 independent measurements and the error bars represent the range of variations among the measurements. The measurements are highly scattered showing that the method is not really quantitative. However, with 9 repetitions it becomes clear that there is a significant difference between $\mathrm{C} 2$ and $\mathrm{C} 4$ on one side with high uptake and $\mathrm{C} 3$ and $\mathrm{C} 5$ on the other with low uptake.

Cross sections of the samples exposed to acid uptake over $200 \mathrm{~h}$ were examined with EDS for phosphorus distribution to show the locations of acid in the GDLs (Figure 3). The mapping confirms a significantly higher acid uptake in $\mathrm{C} 2$ and $\mathrm{C} 4$ than in $\mathrm{C} 3$ and $\mathrm{C} 4$; particularly in the MPLs. C3 and C5 with low overall acid contents contain almost all the acid in the MPLs and hardly anything in the fibrous layers. The difference between $\mathrm{C} 2$ and $\mathrm{C} 4$ and between $\mathrm{C} 3$ and $\mathrm{C} 5$, respectively, is much less pronounced and it is difficult to conclude anything here. However, it appears that C2 has accumulated acid in the outermost part of the fibrous layer and very little in the central part of the fibrous layer.

It is not straight forward to explain the difference in acid uptake and distribution based on the data of table 1. C2 has twice the PTFE content of the other samples in the MPL and it is not to be expected on this background that the acid uptake is among the two highest. C3 has a significantly increased PTFE content in the fibrous layer (extra hydrophobic treatment) and a lower acid affinity is to be expected. Yet the difference between the acid content in the fibrous layers of C3 and C5 is not very significant from a quick glance. It should be noted, however, that the count scale (maximum count number) of the $\mathrm{C} 3$ mapping is twice that of the $\mathrm{C} 5$ 
mapping. This amplifies the counts in the blueish regions, but still the difference is small if any. The most plausible conclusion on the absorption experiments is that finer pore structure of $\mathrm{C} 2$ than $\mathrm{C} 3$, as indicated in Figure 1, is the decisive parameter on top of the PTFE content. One effect that might promote acid accumulation, especially in the fibrous layer, is dehydration of the acid. When acid is located away from the acid pool below and at $160{ }^{\circ} \mathrm{C}$, it will be subject to dehydration and polymerization. This will reduce its mobility and it may form a hydrophilic layer that attracts more acid.

\subsection{Fuel cell test with varied GDL materials in Cathode}

A series of long term fuel cell tests were conducted with anodes made from C2 and cathodes made from $\mathrm{C} 2, \mathrm{C} 3, \mathrm{C} 4$ or $\mathrm{C} 5$. The cells were named by the GDL materials used in the sequence anode/cathode, e.g. cell $\mathrm{C} 2 / \mathrm{C} 3$. Cell voltages at times up to $3500 \mathrm{~h}$ at constant current are plotted in Figure 4. Note that cell C2/C3 was stopped after only 2087 hours due to test bench issues and availability. All cells pass a characteristic break-in period of 100-300 h before peaking. The onward development from here is a practically linear decay over an extended period of time. This behavior is seen for all cells, but at different voltage decay rates. Cell $\mathrm{C} 2 / \mathrm{C} 2$ decays the fastest by $52.8 \mu \mathrm{V} \mathrm{h}^{-1}$ and the other by less than half of that. $\mathrm{C} 2 / \mathrm{C} 3$ and $\mathrm{C} 2 / \mathrm{C} 5$ decay at significantly lower rates than that of $\mathrm{C} 2 / \mathrm{C} 4$. The values read over the time are listed in Table 2. A similar trend is reflected by the rates of acid collection from the fuel cell exhaust. It can be seen from Figure 4 that the acid collection is likewise linear with time and the rates follow the sequence of the voltage decay with the highest acid collection rate corresponding to the highest voltage decay rate. Acid collection rates can also be found in Table 2 .

The cells were subjected to periodical EIS measurements and the high frequency intercept with the real axis of the Nyquist plot (zero phase shift) was taken as the series resistance (ohmic resistance) of the cell at any time during the test as it is a usual practice. Although it comprises contributions from electronic resistances in the electrodes and wires as well as
Wiley-VCH 
contact resistances, it is assumed that the major part of the series resistance can be attributed to the electrolyte and changes are thus assumed to mostly reflect changes in electrolyte resistance. The series resistances over time determined from EIS are plotted in Figure 5. The trends are linear up to $2700 \mathrm{~h}$ and the increase rates are listed in Table 2. Note that the sequence of rates follows that of the voltage decay rates as one might expect. Figure 5 also shows the development of the low frequency intercept too (with subtraction of the high frequency resistance). The interpretation of this is less simple since it may contain contributions from both charge transfer and mass transport. Charge transfer resistance can also be affected by the acid loss since a good acid distribution in the catalyst layer is important for the catalyst utilization. With poor utilization, all of the current has to go through a small fraction of the sites.

Polarizations were recorded at beginning of life (BOL) after $500 \mathrm{~h}$ of operation and at the end of test (EOT). $500 \mathrm{~h}$ was chosen to ensure proper break-in, but it appears, supported by Figure 4, that cell $\mathrm{C} 2 / \mathrm{C} 2$ has already started decaying by then. The other cells performed uniformly at $500 \mathrm{~h}$. At EOT, the cell performance over the whole current density span follows the same trend seen above, i.e. $\mathrm{C} 2 / \mathrm{C} 3>\mathrm{C} 2 / \mathrm{C} 5>\mathrm{C} 2 / \mathrm{C} 4>\mathrm{C} 2 / \mathrm{C} 2$. It should be noted that $\mathrm{C} 2 / \mathrm{C} 3$ was not operated for as long as the other cells.

Post-test phosphorous mapping of cross sections of the four cells are shown in figure 7. Note that $\mathrm{C} 2 / \mathrm{C} 3$ has only been operated for $2087 \mathrm{~h}$ due to test bench issues while the other three cells have been operated for $3508 \mathrm{~h}$. In all cases the anode GDL (left side) contains a significant amount of acid, while the cathode GDL contains much less. This is in accordance with the acid collection as by far the higher amount was collected at the cathode exit (discussed later). This uneven acid distribution is most pronounced for $\mathrm{C} 2 / \mathrm{C} 2$. It is also evident that the coloring of the membrane area of $\mathrm{C} 2 / \mathrm{C} 2$ is returning a lower phosphorous content than the membrane areas of the other cells, even though the count number is much 
higher. This is in good agreement with the fact that cell $\mathrm{C} 2 / \mathrm{C} 2$ degraded the most. The mapping technique is only considered semi-quantitative and the difference between the other three cells is thus somewhat uncertain. An unexpected feature is that the acid contents on the anode side appear to vary considerably. With the same material (C2) in all cells and with the same parameters of operation this is not easily explained. A hypothesis could be that all anode GDLs were initially flooded and that the anodic acid is over time lost via transport to the cathode. This is not obvious since $\mathrm{C} 2 / \mathrm{C} 2$ has the lowest acid content in both membrane and cathode, but still a high (if not highest) content in the anode GDL. A more plausible explanation must be made from a general uncertainty of the mapping itself, the effect of the ion milling sectioning process and the time that elapsed from end of experiment to the measurement. However, it is still sound to conclude that the mapping shows that the acid content (as phosphorous) is significant in the anode GDLs and the acid content in the cathode GDL is much less and the $\mathrm{C} 2 / \mathrm{C} 2$ cell has lost a significant part of its membrane acid.

\subsection{Fuel cell test with interchanging GDLs on both sides}

From the previous section, it appears that the effect of the choice of GDL materials is mainly affecting the acid loss and durability on the cathode side. A number of additional fuel cell tests were made with $\mathrm{C} 2$ and $\mathrm{C} 3$ on the anode side. See Figure 8. The naming is still as the anode/cathode GDL. To save test rig time, the cells were in this case operated only until ca 10 $\%$ voltage decay (nevertheless, the cell C3/C3 then had run for $5512 \mathrm{~h}$ ). C2/C2 and C3/C2 had very similar decay rates after some early disturbance of $\mathrm{C} 2 / \mathrm{C} 2$ that is not explained (the test was interrupted a number of times due to unintentional events). $\mathrm{C} 3 / \mathrm{C} 3$ shows much more stable performance as might be expected based on the results above with $\mathrm{C} 3$ on the cathode side. Like in the previous series of cell tests (Figure 4), the acid collection rate corresponds well with the decay profiles. For $\mathrm{C} 2 / \mathrm{C} 2$ even the effect of the disturbance seems to be reflected and the acid collection rate becomes almost identical to that of $\mathrm{C} 3 / \mathrm{C} 2$ after that. All the degradation rates can be found in Table 2. Additional cells with same combinations of 
GDLs were operated at $887 \mathrm{~h}, 770 \mathrm{~h}$ and $887 \mathrm{~h}$, respectively, but are omitted from Figure 8 for clarity. The resistance developments measured by EIS are plotted in Figure 9. The series resistance increase rates correlate well with the voltage decay rates. Polarization curves were measured for all the cells, but the EOT curves at similar states of degradation were very similar and are thus omitted.

\subsection{General discussion}

The phosphorous mapping reveals that both the MPL and the fibrous layer can contain significant amounts of acid despite wet proofing. The extent of this was not expected. The acid transport from the membrane and into the catalyst layer, the MPL and the fibrous layer is driven by the capillary forces. It is dictated by the pore dimension, the wetting property and surface tension of the acid. It is counterintuitive that the increased content of PTFE did not lead to a reduction of acid in these layers, but hydrophobicity is only acting on the wettability and not necessarily on the pore sizes. It may be that the PTFE is not distributed well into the fine pores of the material and that many of these unaffected pores take up acid regardless of PTFE in other places. It is very clear from the direct uptake measurement that the materials with even number names, $\mathrm{C} 2$ and $\mathrm{C} 4$, made from carbon black; take up much more acid than the materials with odd number names, made from graphitized carbon. It is well-known that carbon black normally has more of the fine pores than graphitized carbon. Graphitization of Vulcan XC-72R carbon black at $2800{ }^{\circ} \mathrm{C}$ for $2 \mathrm{~h}$, for example, resulted in a decrease of the specific surface area from above 200 to $66 \mathrm{~m}^{2} \mathrm{~g}^{-1}$, however, the major loss of the specific surface area of graphitized carbon is due to the elimination of pores smaller than $3.0 \mathrm{~nm}$ [38]. As wet proofing is made after the carbon materials are synthesized and after the pore structure is established, it is easy to imagine that PTFE more easily enters the coarser pores of the C3 and C5 materials. 
With the verification of acid in all layers, it is sound to imagine an acid loss mechanism where acid first moves from the membrane and into the catalyst layer. This is desired and necessary for the utilization of the catalytic sites. Then it moves on further into the MPL and further into the thick fibrous layer and possibly into the flow channels and the bipolar plates. When acid is lost via the gas phase flow, it must evaporate (or form aerosols). Phosphoric acid is used because of its low vapor pressure. It is very low, but not zero. The degree to which the gas flow saturates with acid must depend on the rate of evaporation, which again depends on the surface covered with acid. Had the acid evaporation been limited to the membrane surface, it would have been a slow process and the saturation degree of the gas correspondingly low. Now all the layers are fully or partly wetted which extends the acid surface and enhances the evaporation rate significantly. GDLs that take up acid readily, C2 and C4 will provide better grounds for acid evaporation and thus promote acid loss.

The acid that was collected at the anode and cathode exhausts amounted in all cases to only a few percent of the total acid in the cell, even though several cells were operated for thousands of hours and even though some cells degraded significantly both in terms of voltage and of series resistance. The degradation cannot be explained directly by the amount of collected acid since it would correspond to just a slight variation in doping level. It makes sense anyway. From the point of view of the cell function, acid is lost as soon as it leaves the catalyst layer. Acid vapor will have a strong tendency to re-condense on any surface on its way, including bipolar plates and tubing. One can imagine a process that resembles Knudsen diffusion where molecules repeatedly are halted by adsorption on a surface. This way, the road to freedom is long for the acid molecules even though they count as lost much earlier, namely when they reach the MPL. On this background, acid collection is a poor and very indirect measure of the primary acid loss from the functional parts of the cell (here membrane and catalyst layer). Nevertheless, we do see some correlation between acid collection rate and voltage decay. In Figure 10 acid collection rate and the series resistance increase rate are 
plotted as function of voltage decay rate. Both quantities increase with the voltage decay rate, but in a nonlinear manner with declining curvature. The declining curvature in the case of the acid collection rate can be explained as follows: If voltage decays over time is mostly a direct result of acid loss from the functional parts, then a slow acid loss will result in limited or slow wetting of the layers from which it can evaporate. A fast acid loss into the GDL on the contrary, will result in a higher evaporation rate and then a higher acid collection rate. The dependence on voltage decay rate, i.e. on the primary acid loss, is not linear because with more acid, vapor condensation increases too. Eventually the gas might be saturated and then the collection rate cannot grow any further. We might also see a saturation-like situation when the potential for acid film area is fully utilized and that additional acid just leads to a thicker film. Then the gas stream is perhaps not saturated, but saturation is limited by the evaporation rate which has reached its maximum under the given conditions. The declining curvature of the series resistance plot is simply caused by the increasing contribution from the low frequency resistance from the EIS plots (Figures 5 and 9). Had the total change in cell resistance from EIS been plotted instead, then is should be proportional to the voltage decay rate, since ohms law can then be applied for each point on the graph. The acid collection rate at the cathode exhaust is around two orders of magnitude larger that at the anode. The exit flow is also higher at the cathode, but only by one order of magnitude (with stoichiometry 1.5 and 2 as in this case). The detailed mechanism is more complex and involves enhanced recondensation in the low flow rate case and, perhaps more importantly, the effect of water that is produced at the cathode. Water promotes ortho-phosphoric acid, while lack of water promotes formation of pyro- and meta-phosphoric acid, both of which can be expected to have lower vapor pressures.

Reproducibility is important and should always be demonstrated if possible, but in durability studies it is not only time consuming. When it involves long term occupation of test rigs, it can also be a logistic challenge. We were not able to repeat all the fuel cell experiments for periods of time sufficient to really verify the reproducibility. A number of cells with different Wiley-VCH 
GDLs were operated at shorter periods of up to about $800 \mathrm{~h}$ for subsequent elemental mapping, but the best case was that two C2/C2 cells were operated at $3508 \mathrm{~h}$ and $2084 \mathrm{~h}$ with comparable decay parameters (Table 2). The decay curves are, although shown in two different Figures (4 and 8), very similar. It is not easy to find comparable durability data in literature, because most durability testing is performed at $160{ }^{\circ} \mathrm{C}$ and not at $180{ }^{\circ} \mathrm{C}$ that was deliberately chosen to accelerate the test. However, we do have other durability measurements at $180{ }^{\circ} \mathrm{C}$ from a parallel study in our group. [39] At $200 \mathrm{~mA} \mathrm{~cm}{ }^{-2}$ and $180{ }^{\circ} \mathrm{C}$ and with $\mathrm{C} 2$ on both sides and comparable membrane thickness, the decay rate was ca. $86 \mu \mathrm{V} \mathrm{h}^{-1}$. Note that the gas stoichiometry was 6 for both anode and cathode in contrast to 1.5 and 2 used here. One conclusion the said study makes is that acid loss is a strong function of the gas flow rates and with that in mind, the 38.2 and $52.8 \mu \mathrm{V} \mathrm{h}^{-1}$ measured in the present study are probably not out of the blue.

\section{Conclusions}

In this paper we have investigated effect of the gas diffusion layers (GDL) on the performance decay with time under constant load operation of phosphoric acid doped high-temperature PEM fuel cells. Four commercially available materials were tested and the following can be concluded:

The presence of phosphoric acid was found in both the microporous layer and the fibrous layer of the GDL, increasing with operational time of the fuel cells. It seems that the carbon structure of the microporous layer, plays a more dominating role than the wet proofing effect by PTFE. Of the four GDL materials tested, the two were made from carbon black and had an apparent fine structure. The other two materials were made from graphitized carbon and had a more coarse apparent structure. The fine structured GDLs made from carbon black had a much higher ability to spontaneously take up acid than the two coarse GDL materials made from graphitized carbon. A corresponding difference was seen during stressed acceleration 
tests carried out at $180{ }^{\circ} \mathrm{C}$ (in contrast to the usual $160{ }^{\circ} \mathrm{C}$ ). Long term operation showed faster voltage decay for cells with fine structured GDL's. Voltage decay rate, series resistance increase and acid loss rate (assessed by acid collection at the fuel cell exit) were all in favour of the coarse materials. This effect was by far the most significant on the cathode side where the acid content was found to decreases towards depletion.

The voltage decay rate after an initial break-in of a few hundred hours was rather constant and correlated linearly with the increase of series resistance. It was also correlated with the acid collection rate, although not linearly. The total acid collected over periods of $2000-5500 \mathrm{~h}$ were in all cases below $6 \%$ of the total acid in the cell at start. A loss of this magnitude cannot account directly for the cell degradation seen and the acid collection is thus not a good direct measure of degradation caused by acid loss. Consequently, extrapolation of it to predict end of life of the fuel cell is not sound, though it is an apparent indicator to the acid mobility.

The GDL material was found to be of much higher importance than perhaps long believed. Acid retention on the cathode side plays a crucial role for the endurance of the cell. Operation at $180{ }^{\circ} \mathrm{C}$ for more than $5500 \mathrm{~h}$ with a steady degradation rate of about $12 \mu \mathrm{Vh}^{-1}$ was demonstrated with a coarse GDL based on graphitized carbon in both anode and cathode.

\section{Acknowledgement}

The Danish ForskEl programme is gratefully acknowledge for financial support through the project SmartMEA (no. 2014-1-12218). We thank Larisa Seerup for technical assistance with SEM measurements and Sinh Hy Nguyen from DTU Environment for analyzing samples with ICP-OES. We are thankful for the valuable discussions with Klaus Leister and Achim Bock from Freudenberg and for supplying GDL samples. 


\section{References}

[1] J. S. Wainright and R. F. Savinell. J. Electrochem. Soc. 1995, 142, L121.

[2] A. Chandan, M. Hattenberger, A. El-Kharouf, S. Du, A. Dhir, V. Self, B. G. Pollet, A. Ingram, W. Bujalski, J. Power Sources 2013, 231, 264-278.

[3] U.S. DOE, Fuel Cells Technical Plan, in: Multi-Year Res. Dev. Demonstr. Plan, 2016: p. 18.

[4] T. J. Schmidt, ECS Trans. 2006, 1, 19-31.

[5] Y. Oono, A. Sounai, M. Hori, J. Power Sources 2012, 210, 366-373.

[6] Y. Oono, A. Sounai, M. Hori, J. Power Sources 2013, 241 87-93.

[7] T. Søndergaard, L. N. Cleemann, H. Becker, D. Aili, T. Steenberg, H. A. Hjuler, L. Seerup, Q. Li, J. O. Jensen, J. Power Sources 2017, 342, 570-578.

[8] M. T. D. Jakobsen, J. O. Jensen, in High Temp. Polym. Electrolyte Membr. Fuel Cells, (Eds. Q. Li, D. Aili, H. A. Hjuler, J. O. Jensen), Springer, 2016, pp. 487-509.

[9] D. C. Seel, B. C. Benicewicz, L. Xiao, T. J. Schmidt, B. Fuel, High-temperature polybenzimidazole-based membranes, Handb. Fuel Cells Adv. Electrocatal. Mater. Diagnostics Durab. 5, 6 (2009) 1-13.

[10] Q. F. Li, H. C. Rudbeck, A. Chromik, J. O. Jensen, C. Pan, T. Steenberg, M. Calverley, N. J. Bjerrum, J. Kerres, J. Memb. Sci. 2010, 347 260-270.

[11] D. Aili, L. N. Cleemann, Q. Li, J. O. Jensen, E. Christensen, N. J. Bjerrum, J. Mater. Chem. 2012, 22, 5444.

[12] S. Yu, L. Xiao, B. C. Benicewicz, Fuel Cells 2008, 8 165-174.

[13] J. C. Meier, C. Galeano, I. Katsounaros, J. Witte, H. J. Bongard, A. A. Topalov, C. Baldizzone, S. Mezzavilla, F. Schüth, K. J. J. Mayrhofer, Beilstein J. Nanotechnol. 2014, 5, 44-67.

[14] J. Liao, J. Yang, Q. Li, L. N. Cleemann, J. O. Jensen, N. J. Bjerrum, R. He, W. Xing, J. Power Sources 2013, 238, 516-522.

[15] M. Mamlouk, K. Scott, J. Power Sources 2011, 196 1084-1089.

[16] C. Pan, Q. Li, J. O. Jensen, R. He, L. N. Cleemann, M. S. Nilsson, N. J. Bjerrum, Q. Zeng, J. Power Sources 2007, 172, 278-286.

[17] P. Mazúr, J. Soukup, M. Paidar, K. Bouzek, J. Appl. Electrochem. 2011, 41, 1013-1019.

[18] S. Martin, Q. Li, T. Steenberg, J. O. Jensen, J. Power Sources 2014, 272, 559-566.

[19] N. Pilinski, M. Rastedt, P. Wagner, ECS Trans. 2015, 69, 323-335.

[20] M. V. Williams, E. Begg, L. Bonville, H. R. Kunz, J. M. Fenton, J. Electrochem. Soc. 2004, 151, A1173-1180.

[21] C. Totzke, G. Gaiselmann, M. Osenberg, T. Arlt, H. Markoetter, A. Hilger, A. Kupsch, B. R. Mueller, V. Schmidt, W. Lehnert, I. Manke, J. Power Sources 2016, 324, 625-636.

[22] J. LaManna, S. G. Kandlikar, Proc. 6th Int. Conf. Nanochannels, Microchannels, Minichannels, ICNMM2008, 2008, 1-11. 
[23] S. Galbiati, A. Baricci, A. Casalegno, G. Carcassola, R. Marchesi, Int. J. Hydrogen Energy 2012, 37, 14475-14481.

[24] O. E. Kongstein, T. Berning, B. Børresen, F. Seland, R. Tunold, Energy 2007, 32, 418-422.

[25] J. Lobato, P. Cañizares, M. A. Rodrigo, D. Úbeda, F. J. Pinar, J. J. Linares, Fuel Cells 2010,10 770-777.

[26] F. Mack, T. Morawietz, R. Hiesgen, D. Kramer, V. Gogel, R. Zeis, Int. J. Hydrogen Energy 2016, 41, 7475-7483.

[27] J. Lobato, P. Cañizares, M. A. Rodrigo, C. Ruiz-López, J. J. Linares, J. Appl. Electrochem. 2008, 38, 793-802.

[28] S. Chevalier, M. Fazeli, F. Mack, S. Galbiati, I. Manke, A. Bazylak, R. Zeis, Electrochim. Acta 2016, 212, 187-194.

[29] T. Arlt, W. Maier, C. Tötzke, C. Wannek, H. Markötter, F. Wieder, J. Banhart, W. Lehnert, I. Manke, J. Power Sources 2014, 246 290-298.

[30] S. H. Eberhardt, M. Toulec, F. Marone, M. Stampanoni, F. N. Buchi, T. J. Schmidt, J. Electrochem. Soc. 2015, 162, F310-F316.

[31] S. H. Eberhardt, F. Marone, M. Stampanoni, F. N. Büchi, T. J. Schmidt, J. Electrochem. Soc. 2016, 163 F842-F847.

[32] Y. Oono, T. Fukuda, A. Sounai, M. Hori, J. Power Sources 2010, 195, 10071014.

[33] C. Korte, in Fuel Cell Science and Engineering: Materials, Processes, Systems and Technology. Vol. 1 (Eds. D. Stolten, B. Emonts) Wiley VCH 2012, 335-359.

[34] F. N. Büchi, T. J. Schmidt S. H. Eberhardt, T. Lochner, J. Electrochem. Soc. 2015, 162, 1367-1372.

[35] W. Maier, T. Arlt, C. Wannek, I. Manke, H. Riesemeier, P. Krüger, J. Scholta, W. Lehnert, J. Banhart, D. Stolten, Electrochem. Commun. 2010, 12, 14361438.

[36] T. Mori, J. Imahashi, T. Kamo, K. Tamura, Y. Hishinuma, J. Electrochem. Soc. 1986, 133, 896.

[37] F. Liu, S. Mohajeri, Y. Di, K. Wippermann, W. Lehnert, Fuel Cells 2014, 14, 750-757.

[38] L. N. Cleemann, F. Buazar, Q. Li, J. O. Jensen, C. Pan, T. Steenberg, S. Dai, N. J. Bjerrum, Fuel Cells 2013, 13, 822-831.

[39] T. Søndergaard, L. N. Cleemann, H. Becker, T. Steenberg, H. A. Hjuler, L. Seerup, Q. Li and J. O. Jensen, submitted to J. Electrochem. Soc. 
Fig. 1 SEM images of the MPL side of materials C2 and C3.

(Figure column wide)

Fig. 2 Acid uptake for the GDLs C2, C3, C4, and C5. The error bars represent the total span of 9 measurements for each data point.

(Figure column wide)

Fig. 3 EDS mapping of Phosphorus distribution in the electrode supports after acid uptake over $200 \mathrm{~h}$. The microporous layer in contact with the acid is located in the left side of the images. The remaining major parts are the fibrous layers. The color coding indicates count density and highest values are given in the white fields.

(Figure column wide)

Fig. 4 Durability of cells with varied GDL on the cathode side (solid lines) and cumulative acid collected at the fuel cells exhaust (dotted line). The cells were operated at $180{ }^{\circ} \mathrm{C}, 200$ $\mathrm{mA} \mathrm{cm}{ }^{-2}, \lambda_{\mathrm{H} 2}=1.5$ and $\lambda_{\text {air }}=2$. The cell identification is by the anode/cathode GDL.

(Figure page wide)

Fig. 5 Evolution of cell resistances during the test shown in Figure 4 of cells with varied cathode GDLs. The GDL combinations are indicated on the figure.

(Figure column wide)

Fig. 6 Polarization curves of cells measured with varied GDLs on cathode during beginning of life (BOL) and end of test (EOT).

(Figure page wide) 
Fig. 7 Phosphorus mapping of cross sections of the MEA with varied GDLs after EOT. The distinct bands of ca. $35 \mu \mathrm{m}$ in the middle of the figures are the membranes. The anodes are on the left sides. The cell identification is anode/cathode.

(Figure column wide)

Fig. 8 Durability of cells with varied GDL on the both sides and cumulative acid collected at the fuel cells exhaust. The cells were operated at $180{ }^{\circ} \mathrm{C}, 200 \mathrm{~mA} \mathrm{~cm}{ }^{-2}, \lambda_{\mathrm{H}_{2}}=1.5$ and $\lambda_{\text {air }}=2$. The cell identification is anode/cathode.

(Figure page wide)

Fig. 9. Evolution of cell resistances during the test shown in Figure 8. GDL combinations are indicated on the figure.

(Figure column wide)

Fig. 10 Acid collection rate and series resistance increase rate as a function of voltage decay rate. Data from Table 2.

(Figure column wide) 
Table 1. Properties of gas diffusion layer materials from the supplier (Freudenberg datasheet). Values in italics are estimated by EDS in this work.

\begin{tabular}{|c|c|c|c|c|}
\hline Product Name (short) & $\begin{array}{l}\mathrm{H} 23 \mathrm{C} 2 \\
(\mathrm{C} 2)\end{array}$ & $\begin{array}{c}\mathrm{H} 23 \mathrm{C} 4 \\
(\mathrm{C} 4)\end{array}$ & $\begin{array}{c}\mathrm{H} 24 \mathrm{C} 3 \\
(\mathrm{C} 3)\end{array}$ & $\begin{array}{l}\mathrm{H} 24 \mathrm{C} 5 \\
(\mathrm{C} 5)\end{array}$ \\
\hline Carbon in MPL & Carbon black & Carbon black & $\begin{array}{l}\text { Graphitized } \\
\text { carbon }\end{array}$ & $\begin{array}{l}\text { Graphitized } \\
\text { carbon }\end{array}$ \\
\hline $\begin{array}{l}\text { Wet proof of the fibrous } \\
\text { substrate }\end{array}$ & Yes & Yes & Extra & Yes \\
\hline PTFE in MPL $/ w t \%$ & 40 & 20 & 20 & 20 \\
\hline $\begin{array}{l}\text { PTFE in MPL } / \text { wt } \% \\
\text { (measured, this work) }\end{array}$ & 46.8 & 23.4 & 24.5 & 23 \\
\hline $\begin{array}{l}\text { PTFE in fibrous layer } / w t \% \\
\text { (measured, this work) }\end{array}$ & 2.6 & 2.6 & 11.8 & 3.2 \\
\hline Thickness / $\mu \mathrm{m}$ & 215 & 215 & 230 & 215 \\
\hline Areal weight $/ \mathrm{gm}^{-2}$ & 135 & 135 & 150 & 130 \\
\hline Electrical resistance $/ \mathrm{m} \Omega . \mathrm{cm}^{-2}$ & 10 & 8 & 9 & 9 \\
\hline Tensile strength $/ \mathrm{Nmm}^{-1}$ & 1.6 & 1.2 & 1.4 & 1.4 \\
\hline
\end{tabular}


Table 2 Summary of voltage, resistance and acid loss

\begin{tabular}{cccccc} 
Cell & $\begin{array}{c}\text { Test time } \\
/ \mathrm{h}\end{array}$ & $\begin{array}{c}\text { Voltage Decay } \\
\text { rate } \\
/ \mu \mathrm{Vh}^{-1}\end{array}$ & $\begin{array}{c}\text { Series } \\
\text { resistance } \\
\text { increase rate } \\
/ \mu \Omega \mathrm{h}^{-1}\end{array}$ & $\begin{array}{c}\text { Acid loss rate } \\
\left(\begin{array}{c}\text { anode/cathode }) \\
/ \mathrm{ngcm}^{-2} \mathrm{~h}^{-1}\end{array}\right.\end{array}$ & $\begin{array}{c}\text { Acid loss } \\
/ \%\end{array}$ \\
\hline $\mathrm{C} 2 / \mathrm{C} 2$ & 3508 & 52.8 & 2.9 & $0.58 / 147$ & 5.5 \\
$\mathrm{C} 2 / \mathrm{C} 4$ & 3508 & 23.7 & 1.7 & $0.85 / 128$ & 4.8 \\
$\mathrm{C} 2 / \mathrm{C} 5$ & 3508 & 11.1 & 0.39 & $0.95 / 102$ & 3.8 \\
$\mathrm{C} 2 / \mathrm{C} 3$ & 2086 & 10.8 & 0.48 & $1.41 / 101$ & 2.3 \\
$\mathrm{C} 2 / \mathrm{C} 2 \mathrm{II}$ & 2084 & 38.2 & 2.5 & $0.45 / 150$ & 3.4 \\
$\mathrm{C} 3 / \mathrm{C} 2$ & 3430 & 26.7 & 1.6 & $0.22 / 126$ & 4.7 \\
$\mathrm{C} 3 / \mathrm{C} 3$ & 5512 & 12.5 & 0.86 & $0.44 / 100$ & 5.9
\end{tabular}




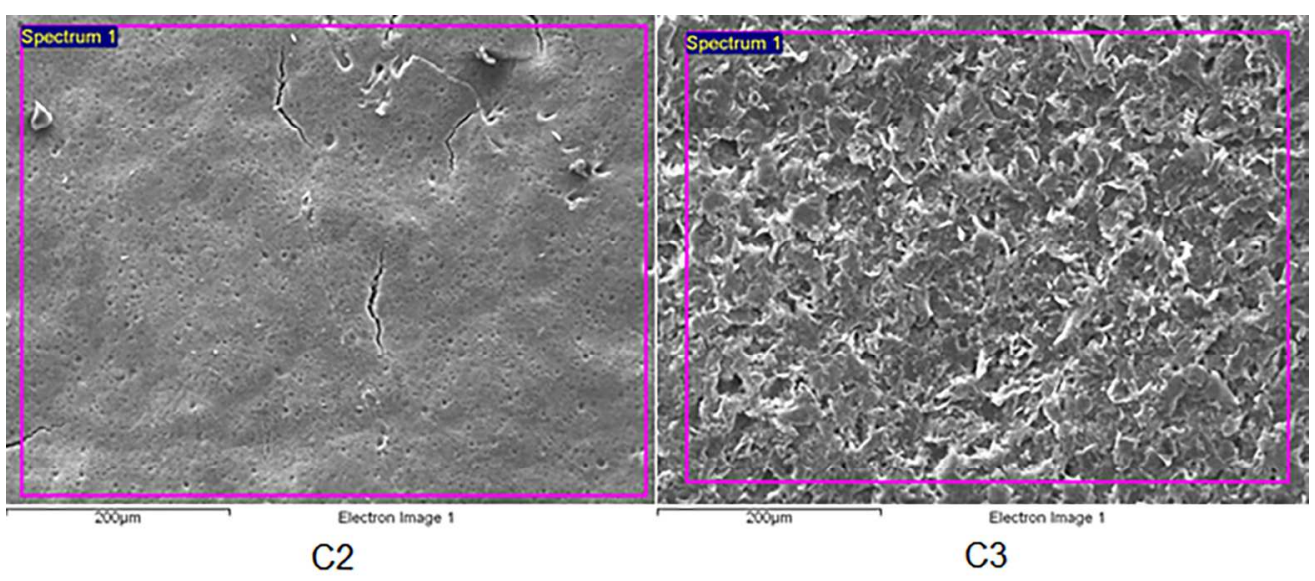

Fig. 1 SEM images of the MPL side of materials C2 and C3.

(Figure column wide)

$160 \times 69 \mathrm{~mm}(300 \times 300 \mathrm{DPI})$ 
Fig. 2 Acid uptake for the GDLs C2, C3, C4, and C5. The error bars represent the total span of 9 measurements for each data point.

\section{(Figure column wide)}

$209 \times 148 \mathrm{~mm}(300 \times 300$ DPI $)$ 


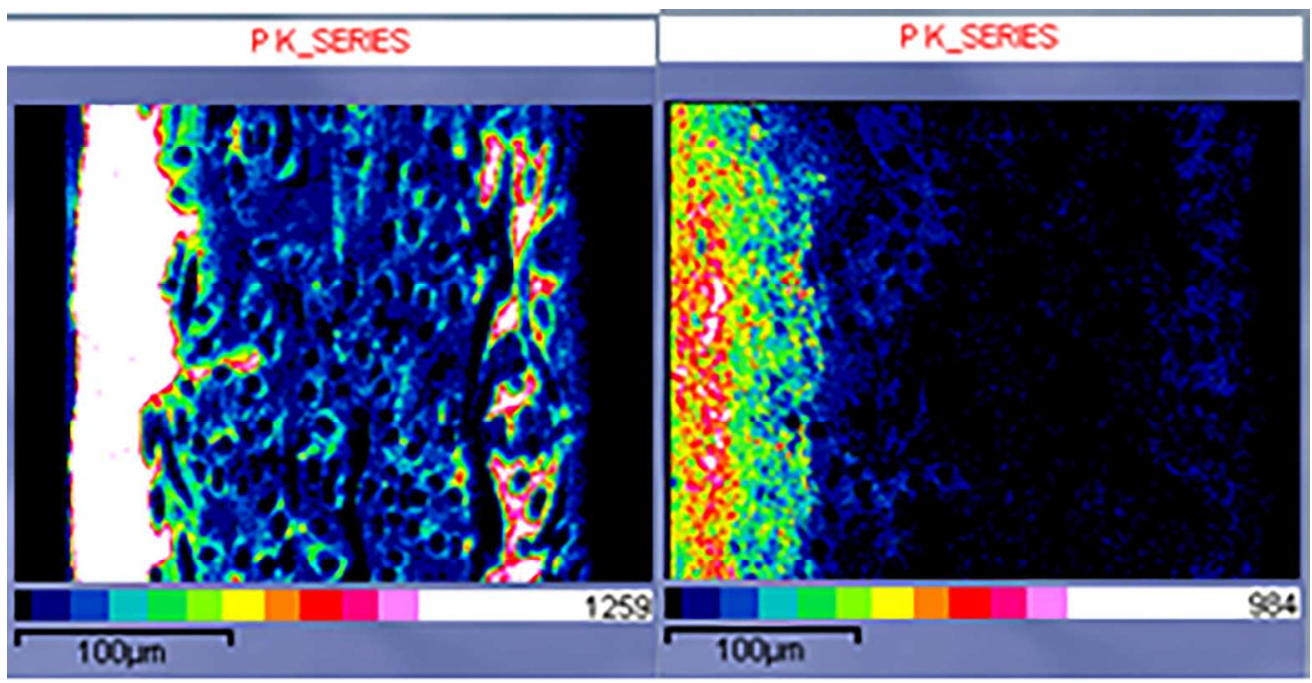

\section{C2}

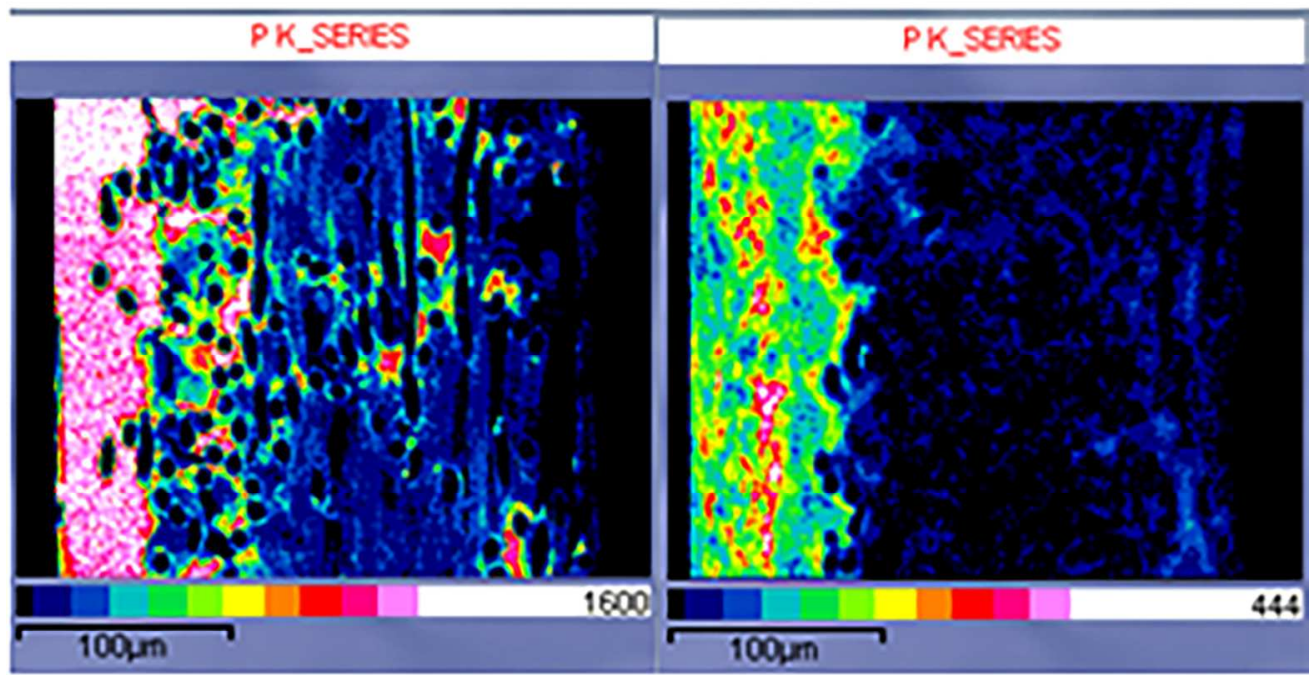

C4

\section{C5}

Fig. 3 EDS mapping of Phosphorus distribution in the electrode supports after acid uptake over $200 \mathrm{~h}$. The microporous layer in contact with the acid is located in the left side of the images. The remaining major parts are the fibrous layers. The colour coding indicates count density and highest values are given in the white fields.

(Figure column wide)

$160 \times 185 \mathrm{~mm}(300 \times 300 \mathrm{DPI})$ 


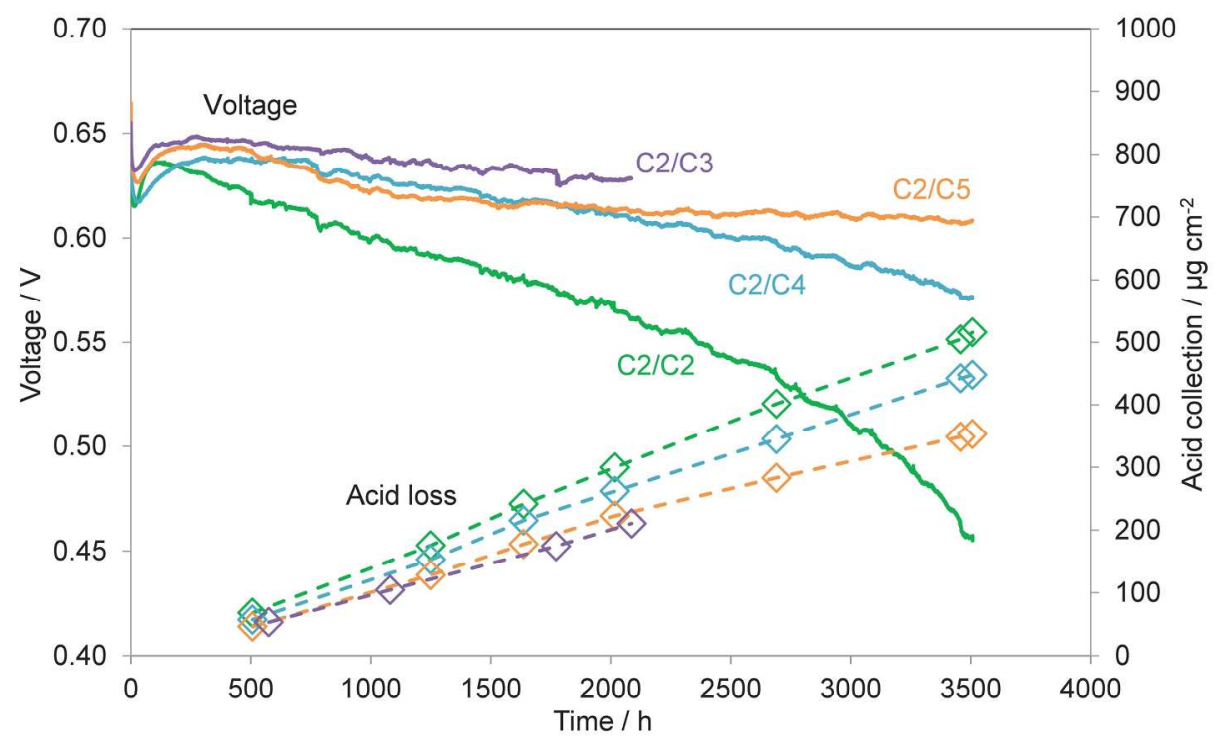

Fig. 4 Durability of cells with varied GDL on the cathode side (solid lines) and cumulative acid collected at the fuel cells exhaust (dotted line). The cells were operated at $180^{\circ} \mathrm{C}, 200 \mathrm{~mA} \mathrm{~cm}{ }^{-2}, \lambda_{\mathrm{H} 2}=1.5$ and $\lambda_{\text {air }}=2$. The cell identification is by the anode/cathode GDL.

(Figure page wide)

$209 \times 148 \mathrm{~mm}(300 \times 300 \mathrm{DPI})$ 


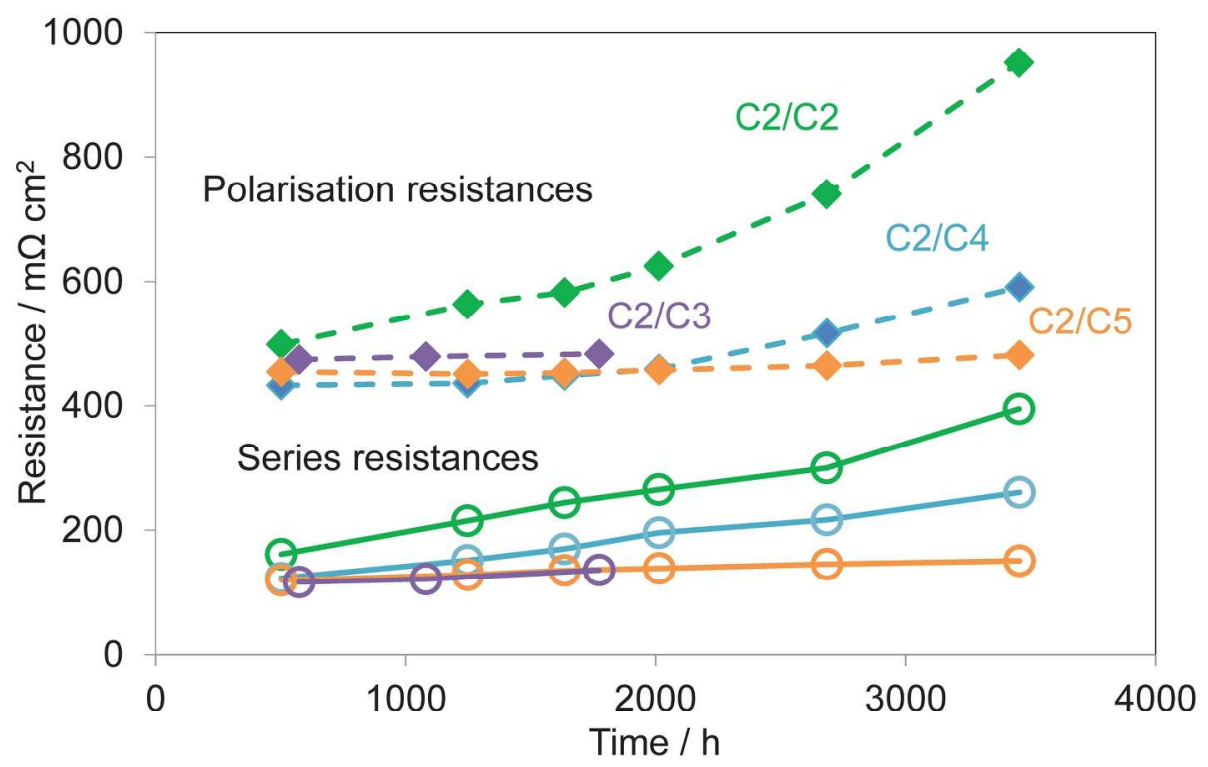

Fig. 5 Evolution of cell resistances during the test shown in Figure 4 of cells with varied cathode GDLs. The GDL combinations are indicated on the figure.

(Figure column wide)

$209 \times 148 \mathrm{~mm}(300 \times 300$ DPI $)$ 
Fig. 6 Polarization curves of cells measured with varied GDLs on cathode during beginning of life (BOL) and end of test (EOT).

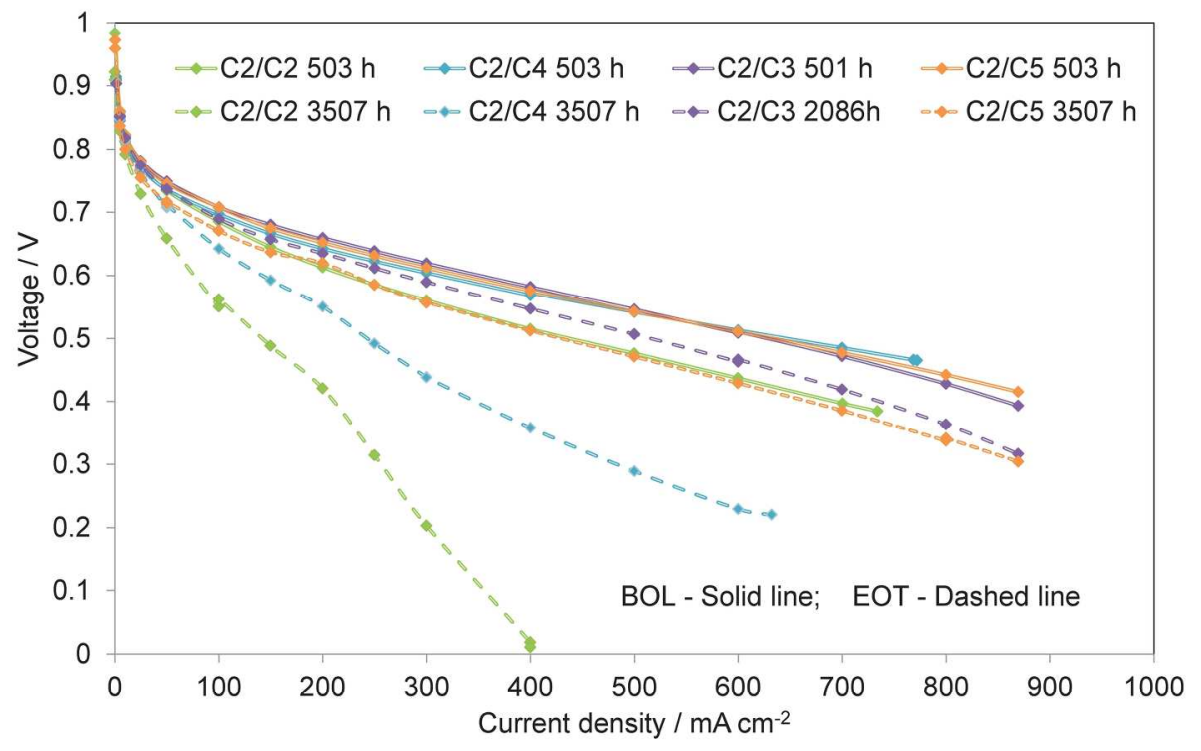

(Figure page wide)

$209 \times 148 \mathrm{~mm}(300 \times 300$ DPI $)$ 


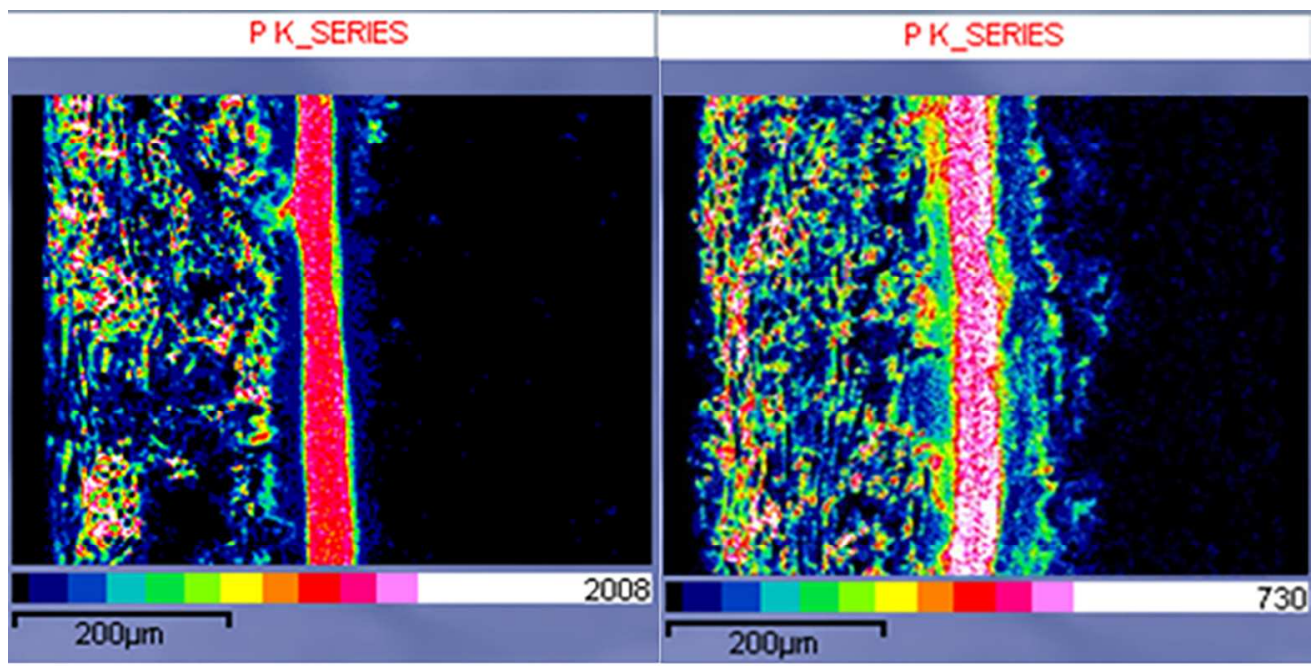
a. C2/C2 - $3508 \mathrm{~h}$
c. $\mathrm{C} 2 / \mathrm{C} 3-2087 \mathrm{~h}$
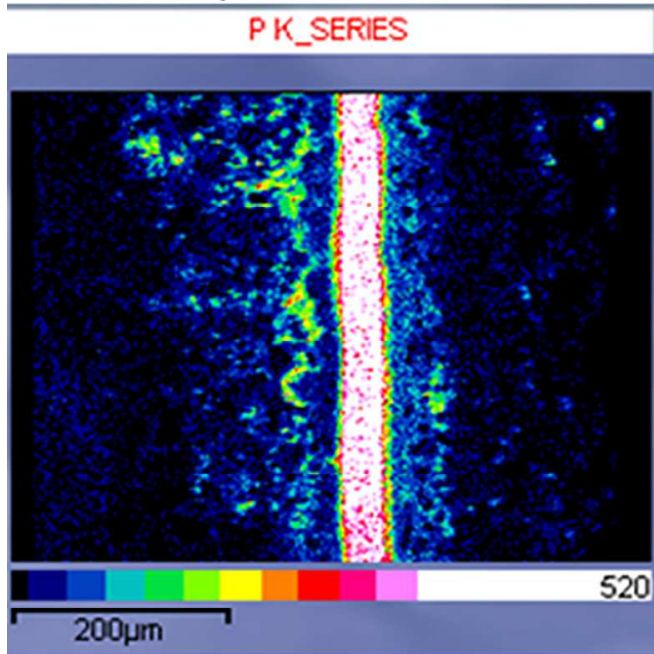

520

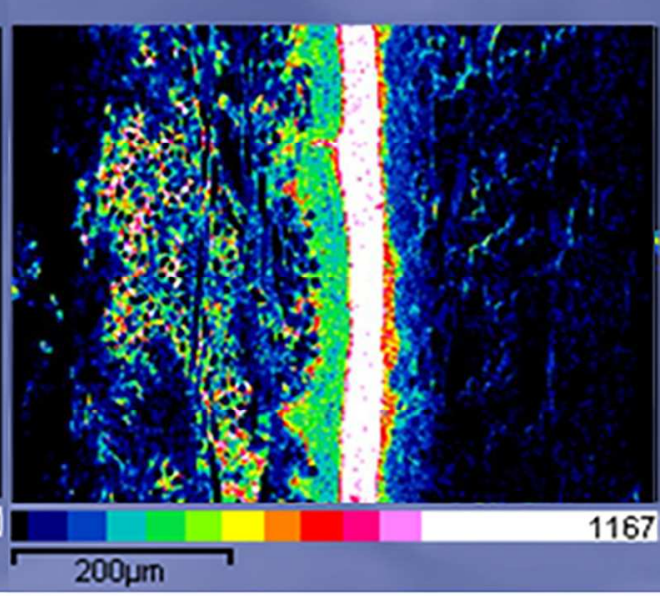

b. $C 2 / C 4-3508 h$

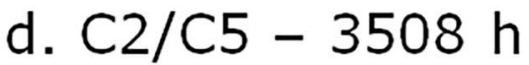

Fig. 7 Phosphorus mapping of cross sections of the MEA with varied GDLs after EOT. The distinct bands of ca. $35 \mu \mathrm{m}$ in the middle of the figures are the membranes. The anodes are on the left sides. The cell identification is anode/cathode.

(Figure column wide)

$160 \times 180 \mathrm{~mm}(300 \times 300 \mathrm{DPI})$ 


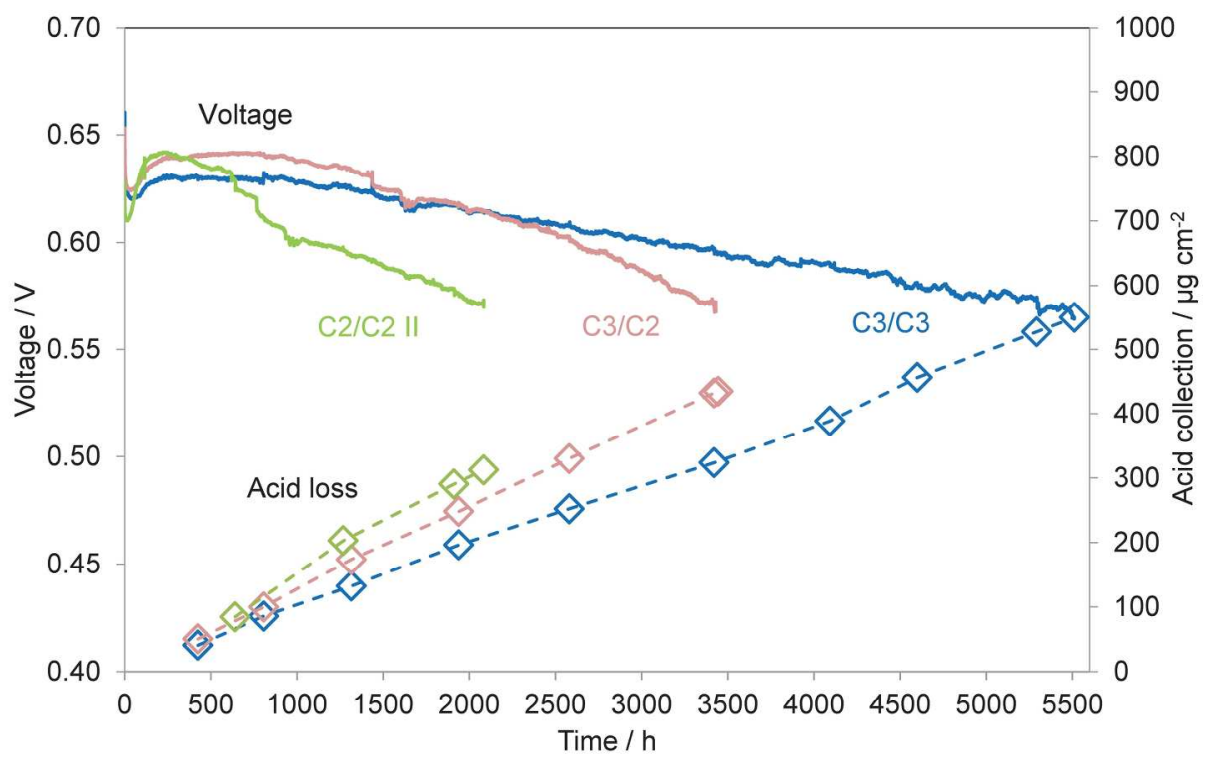

Fig. 8 Durability of cells with varied GDL on the both sides and cumulative acid collected at the fuel cells exhaust. The cells were operated at $180^{\circ} \mathrm{C}, 200 \mathrm{~mA} \mathrm{~cm}{ }^{-2}, \lambda_{\mathrm{H} 2}=1.5$ and $\lambda_{\text {air }}=2$. The cell identification is anode/cathode.

(Figure page wide)

$209 \times 148 \mathrm{~mm}(300 \times 300 \mathrm{DPI})$ 


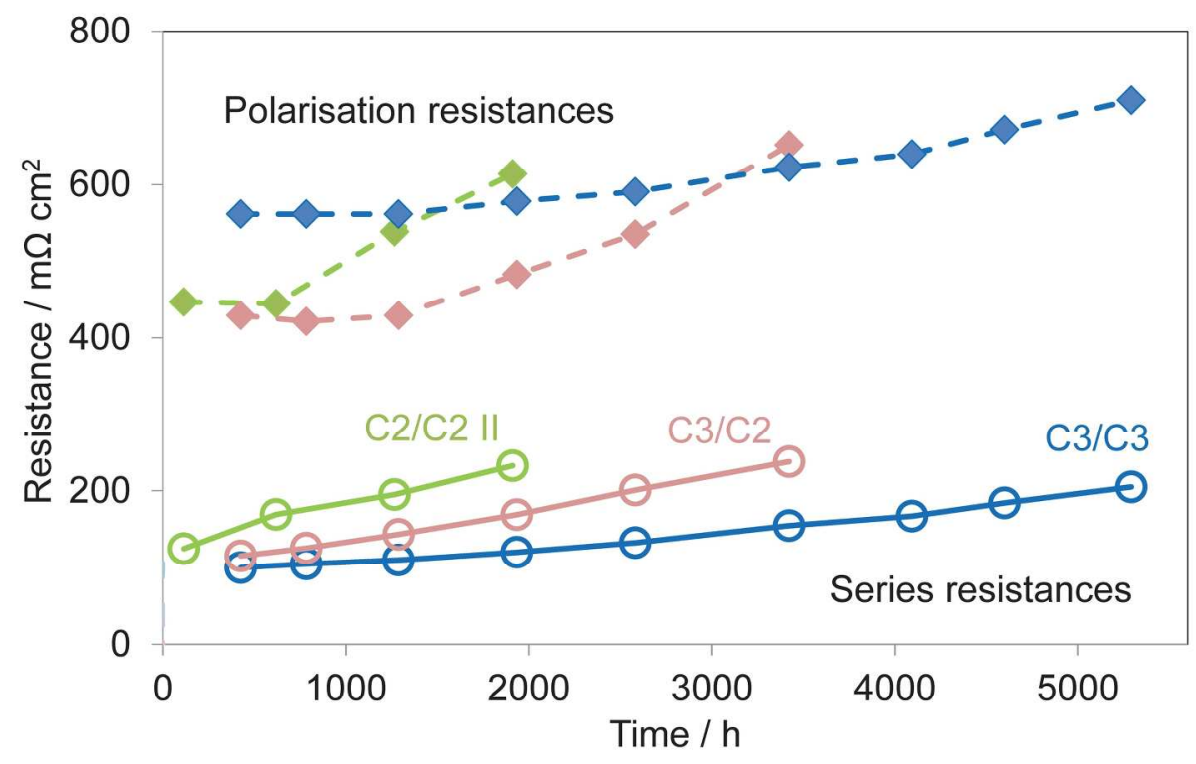

Fig. 9. Evolution of cell resistances during the test shown in Figure 8. GDL combinations are indicated on the figure.

(Figure column wide)

$209 \times 148 \mathrm{~mm}(300 \times 300$ DPI $)$ 
1

2

3

4

5

6

7

8

10

11

12

14

15

16

17

18

19

20

21

22

23

24

25

26

27

28

29

30

31

32

33

34

35

36

37

38

39

40

41

42

43

44

45

46

47

48

49

50

51

52

53

54

55

56

57

58

59

60

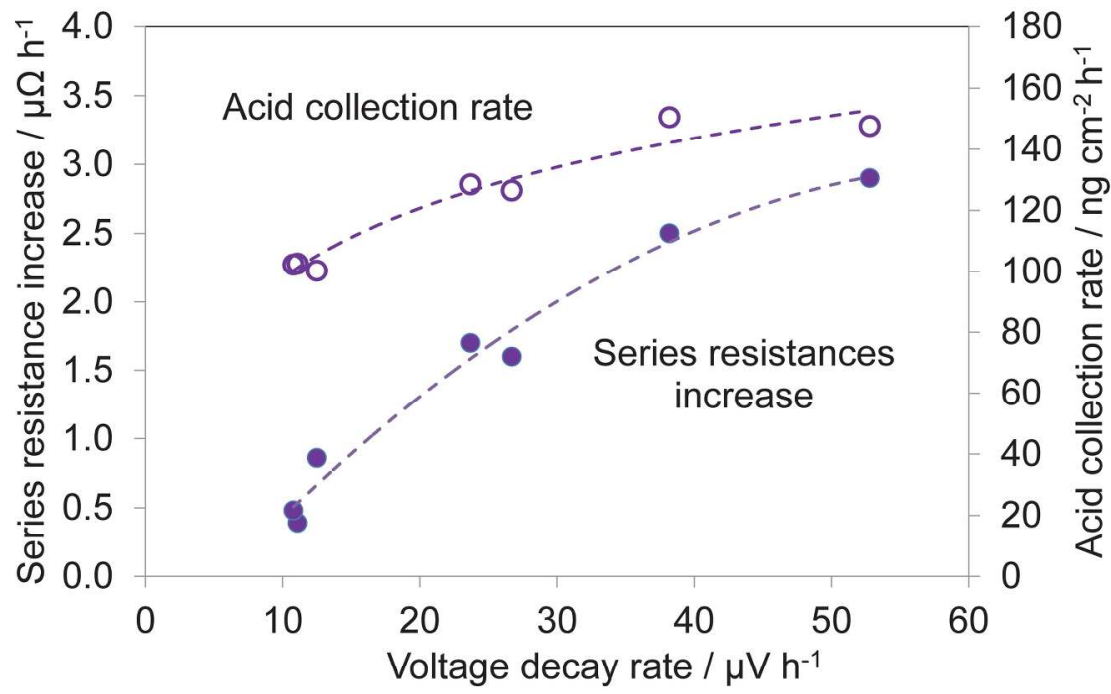

Fig. 10 Acid collection rate and series resistance increase rate as a function of voltage decay rate. Data from Table 2.

(Figure column wide)

$209 \times 148 \mathrm{~mm}(300 \times 300$ DPI $)$ 